\title{
Neurocysticercosis (NCC) vs Central Nervous System (CNS) Tuberculoma in Children- Dilemma over Clinico-Radiological Diagnosis?
}

\author{
Bharat-Bhushan Sharma ${ }^{1}$, Shashi Sharma ${ }^{2}$ \\ ${ }^{1}$ Department of Radio-Diagnosis, SGT Medical College, Gurgaon, India \\ ${ }^{2}$ Department of Pediatrics, SGT Medical College, Gurgaon, India \\ Email: bbhushan986@gmail.com, shashi.s986@gmail.com
}

How to cite this paper: Sharma, B.-B. and Sharma, S. (2016) Neurocysticercosis (NCC) vs Central Nervous System (CNS) Tuberculoma in Children-Dilemma over ClinicoRadiological Diagnosis? Open Journal of Pediatrics, 6, 245-251.

http://dx.doi.org/10.4236/ojped.2016.63034

Received: August 29, 2016

Accepted: September 13, 2016

Published: September 16, 2016

Copyright $\odot 2016$ by authors and Scientific Research Publishing Inc. This work is licensed under the Creative Commons Attribution International License (CC BY 4.0).

http://creativecommons.org/licenses/by/4.0/

\begin{abstract}
Background: Neurocysticercosis (NCC) and central nervous system (CNS) tuberculomas often overlap in clinical presentation and imaging. Though the aetio-pathology entirely differs in both the scenarios but there is great confusion in their clinicoradiological evaluation as the findings and appearances are similar in many ways. The stress should be laid out over the salient features of each entity in the background of their presentation. The study was conducted to highlight the differentiation of the clinico-radiological findings in both the entities. Material and Methods: Ten patients between 5 - 15 years (mean age 10.4 years) with complaints of headache and with or without seizures had undergone MRI alone or with CT examinations. Basic sequences of T1W, T2W, T2W FLAIR and T1W contrast studies were carried out in all the cases. CT was carried out in only three cases and contrast was given in two cases. Results: Eight patients were having ring enhancing lesions in post contrast studies in MRI and two had only cystic lesions ranging from $1-3 \mathrm{~cm}$ in diameter. Conclusion: Seven cases having tuberculomas were confirmed by both the modalities with one case inconclusive. Two cases were diagnosed as neurocysticercosis as per the results. The reasonable achievable target was the goal to differentiate between NCC and tuberculomas in the brain and it was achieved. Contrast MRI and spectroscopy brought out many findings for the distinct features in many cases.
\end{abstract}

\section{Keywords}

Neurocysticercosis, Tuberculomas, Seizures, CT, MRI

\section{Introduction}

Neurocysticercosis is caused by pork tapeworm where human acts as intermediate host. 
The clinical presentation varies from $1-30$ years in their manifestations. Escobar's four stages have got their own presentations and clinical features.

\section{Patients and Methods}

Ten patients with the history of headache and with or without seizures were subjected to CT and MRI examinations. Eight cases were from the rural poor socioeconomically background. Two cases were from urban background and their parents were from teaching profession. MRI was done with 1.5 T Phillips Multiva Whole Body MR Scanner and CT was done with 16 slices Siemens Scope Whole Body CT Scanner. In our study of ten patients, six have undergone both MRI and CT and other four have been subjected to MRI only. The main aim was to avoid radiation exposure wherever it was possible especially in female children. Two cases (Case 3 and Case 10) required mild sedation for MRI study. Plain as well as contrast CT studies were carried out. MRI was done with T1W, T2W, T2W FLAIR and T1W contrast studies. MR spectroscopy was done in five cases.

\section{Inclusion and Exclusion Criteria}

All the fresh cases were included. No child who had previous history of trauma, under treatment for seizures or any systemic disease was included. All the cases that had birth asphyxia, congenital malformation or bad perinatal history were excluded from the study.

\section{Results}

In our study four patients were diagnosed as having NCC and six were diagnosed as that of CNS tuberculomas. All patients with tuberculomas were having multiple lesions and all have shown ring enhancement pattern. Most of the lesions were predominantly situated in the posterior fossa. Out of four NCC cases two (50\%) have shown amino acid peak in MR spectroscopy and other two were non specific. Three cases of tuberculomas where spectroscopy was done had shown the lipid peak along with choline and decrease in NAA peak (100\%). Five out of six tuberculomas patients have come with seizures $(80 \%)$ as compared to one (33\%) out of three NCC cases. Serological tests have shown and supported the radiological findings where ever done. The chart has been given below for the various findings in the cases of our study (Table 1).

10 years old female child (Case 1) who presented with headache underwent only MRI examination and the classical findings of cysts in neurocysticercosis were found. This was confirmed in spectroscopy with amino acid peak. Serlological studies were not required as the scolex head was seen as hypointense dot (Figures 1(a)-(c)).

Another 12 years old male child (Case 4) underwent contrast MRI studies with the complaints of generalized seizures of one year duration. The investigations have revealed multiple ring enhancing lesions diffusely spread in the whole brain. There was evidence of raised intracranial tension also. Few of the lesions have shown conglomeration (Figures 2(a)-(d)).

7 years old female child has reported with the complaints of abnormal movements of 
Table 1. Findings of our study (ten cases) of NCC and CNS tuberculomas.

\begin{tabular}{|c|c|c|c|c|c|c|c|c|c|c|}
\hline S. No. & Age $(\mathrm{Y})$ & Sex & Complaints & MRI & CT & $\begin{array}{c}\text { Neurological } \\
\text { deficit }\end{array}$ & $\begin{array}{c}\text { Single/multiple } \\
\text { lesions }\end{array}$ & $\begin{array}{c}\text { Spectroscopy } \\
\text { findings }\end{array}$ & $\begin{array}{l}\text { Serological } \\
\text { findings }\end{array}$ & Diagnosis \\
\hline Case 1 & 10 & $\mathrm{~F}$ & $\begin{array}{l}\text { Headache of } \\
1 \text { year }\end{array}$ & $\begin{array}{l}\text { Multiple cysts } \\
\text { of varying sizes } \\
\text { with dot sign } \\
\text { (parasitic scolex) }\end{array}$ & - & - & Multiple & $\begin{array}{l}\text { Amino acid } \\
\text { peak }\end{array}$ & - & $\begin{array}{l}\text { Neurocysticercosis } \\
\text { (NCC) }\end{array}$ \\
\hline Case 2 & 15 & M & $\begin{array}{l}\text { Headache and } \\
\text { seizures } 3 \\
\text { months }\end{array}$ & $\begin{array}{l}\text { Multiple } \\
\text { supra-tentorial } \\
\text { cystic lesion }\end{array}$ & $\begin{array}{l}\text { Multiple cystic } \\
\text { lesion without } \\
\text { enhancement }\end{array}$ & $\begin{array}{l}\text { Not } \\
\text { present }\end{array}$ & Multiple & $\begin{array}{l}\text { Amino acid } \\
\text { peak }\end{array}$ & $\begin{array}{l}\text { ELISA + ve } \\
\text { (Enzyme-linked } \\
\text { immunosorbent } \\
\text { assay) }\end{array}$ & NCC \\
\hline Case 3 & 5 & $\mathrm{~F}$ & $\begin{array}{l}\text { Seizures } \\
2 \text { months }\end{array}$ & $\begin{array}{l}\text { Pos fossa ring } \\
\text { enhancing } \\
\text { multiple lesion }\end{array}$ & - & $\begin{array}{l}\text { Not } \\
\text { present }\end{array}$ & Multiple & --- & ELISA+ & Tuberculoma \\
\hline Case 4 & 12 & $\mathrm{M}$ & $\begin{array}{l}\text { Generalised } \\
\text { tonic clonic } \\
\text { seizures of } \\
1 \text { year }\end{array}$ & $\begin{array}{l}\text { Multiple } \\
\text { conglomerated } \\
\text { lesions } \\
\text { with ring } \\
\text { enhancement }\end{array}$ & $\begin{array}{l}\text { Multiple } \\
\text { hypodense } \\
\text { lesions } \\
\text { with ring } \\
\text { enhancement }\end{array}$ & $\begin{array}{l}\text { Raised } \\
\text { intracranial } \\
\text { tension } \\
\text { (ICT) }\end{array}$ & Multiple & $\begin{array}{l}\text { Lipid-lactate } \\
\text { peak with } \\
\text { decline in } \\
\text { NACC peak }\end{array}$ & ------ & Tuberculomas \\
\hline Case 5 & 14 & M & $\begin{array}{l}\text { Seizures (movements } \\
\text { of left side of the } \\
\text { body) } 6 \text { months }\end{array}$ & Single lesion & - & $\begin{array}{l}\text { Not } \\
\text { present }\end{array}$ & Single & Lipid peak & ------- & Tuberculoma \\
\hline Case 6 & 10 & $\mathrm{~F}$ & $\begin{array}{l}\text { Headache \& } \\
\text { vomitting }\end{array}$ & Single & $\begin{array}{l}\text { Ring } \\
\text { enhancing } \\
\text { lesion }\end{array}$ & $\begin{array}{l}\text { Not } \\
\text { present }\end{array}$ & Single & Non specific & $\begin{array}{l}\text { ELITB + ve } \\
\text { (Enzyme-linked } \\
\text { immunotransfer } \\
\text { blot Technique) }\end{array}$ & NCC \\
\hline Case 7 & 13 & M & $\begin{array}{l}\text { Headache and } \\
\text { Seizures } \\
1 \text { y } 6 \text { months }\end{array}$ & $\begin{array}{l}\text { Supra tentorial } \\
\text { multiple ring } \\
\text { enhancing } \\
\text { lesions }\end{array}$ & $\begin{array}{l}\text { Supratentorial } \\
\text { multiple ring } \\
\text { enhancing } \\
\text { lesions }\end{array}$ & $\begin{array}{l}\text { Raised } \\
\text { intracranial } \\
\text { tension } \\
\text { (ICT) }\end{array}$ & Multiple & & --.-- & Tuberculoma \\
\hline Case 8 & 7 & $\mathrm{~F}$ & $\begin{array}{l}\text { Seizures (movement } \\
\text { of right side of the } \\
\text { body) } 2 \text { months }\end{array}$ & $\begin{array}{l}\text { Left parietal ring } \\
\text { enhancing lesion }\end{array}$ & - & $\begin{array}{l}\text { Not } \\
\text { present }\end{array}$ & Two & $\begin{array}{l}\text { Lipid peak } \\
\text { with decrease } \\
\text { in NAA peak }\end{array}$ & & Tuberculoma \\
\hline Case 9 & 12 & M & $\begin{array}{l}\text { Headache } \\
\text { and seizures } \\
1 \text { year }\end{array}$ & $\begin{array}{l}\text { No ring } \\
\text { enhancement }\end{array}$ & $\begin{array}{l}\text { Two small cystic } \\
\text { lesions with } \\
\text { dot sign }\end{array}$ & $\begin{array}{l}\text { Not } \\
\text { present }\end{array}$ & Two & Non specific & ELITB+ & NCC \\
\hline Case 10 & 6 & M & $\begin{array}{l}\text { Seizures } 2 \\
\text { months }\end{array}$ & $\begin{array}{l}\text { Peripheral } \\
\text { enhancement } \\
\text { is present }\end{array}$ & $\begin{array}{l}\text { Infratentorial } \\
\text { conglomerated } \\
\text { lesions }\end{array}$ & $\begin{array}{l}\text { Enhancing } \\
\text { lesions }\end{array}$ & Multiple & -- & ELISA+ & Tuberculoma \\
\hline
\end{tabular}

the right side of the body. Contrast MR T1W sequence has shown two ring enhancing lesions. The bigger one was present in the left high parietal region with extensive perilesional oedema. This was thought to be of some malignant pathology but MR spectroscopy has shown lipid peak consistent with tuberculomas (Figure 3(a) and Figure 3(b) and Figure 4). 


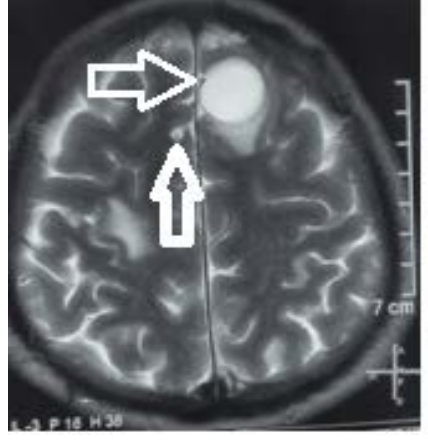

(a)

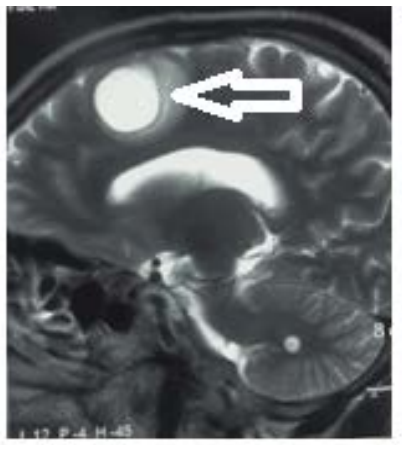

(b)

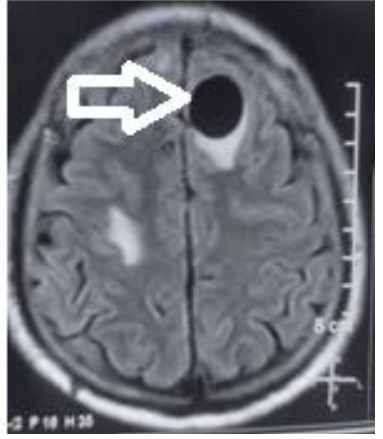

(c)

Figure 1. Case 1 of brain MRI of 10 years old female child. (a) T2W axial section shows a well defined hyperintense lesion in left fronto-parietal region with eccentric hypointense "dot sign" depicting the scolex head (white arrows). (b) T2WI sagittal section further delineates round hyperintense lesion with surrounding vasogenic edema. (c) T2W FLAIR axial section shows the behavior of the lesion as hypointense cystic (white arrow) with minimal surrounding edema.

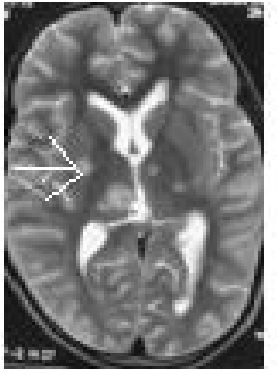

(a)

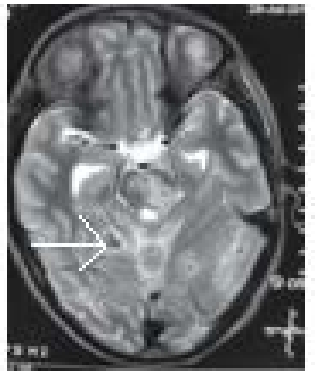

(b)

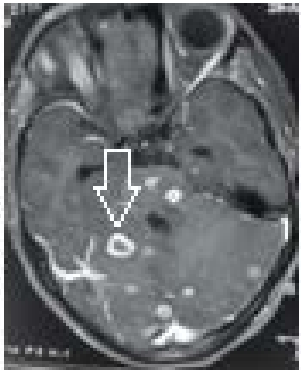

(c)

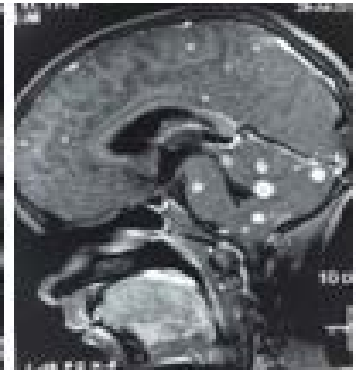

(d)

Figure 2. Case 4 of brain MRI of 12 years old male child. (a) T2WI axial section shows small cysts in right cerebral hemisphere (white arrow). (b) T2WI axial section at lower level shows another cystic lesion (white arrow). (c) T1W post gadopentetate-dimeglumine contrast axial section shows ring enhancement (white arrow). (d) Post contrast TIW sagittal section shows multiple ring enhancing small lesions spread in whole brain.

\section{Discussion}

CNS tuberculomas and neurocysticercosis brain parenchymal lesions have got many similarities in the symptomatologies. Neuroimaging and serological assay always confirm the diagnosis. There are also large gamut of pathologies where there is presence of "ring enhancing lesion" confuses the exact diagnosis. In addition to the clinical background the dilemma persists for the confirmative diagnosis. MRI and CT bring out some differentiations between the lesion morphological features. If these are combined with serological findings then the reasonable diagnosis is achieved. Magnetic resonance features have been compared in both the pathologies highlighting the imaging characteristics in each case (Figure 5). Neurocysticercosis of CNS takes place when larval stage of Taenia solium invades it [1]. This is the zoonotic cestode transmitted between the human and pig. The sensitivity of the serological test is less $(<50 \%)$, so the other radiological imaging studies findings play a crucial role [2]. The treatment is started with anticonvulsants and a twelve days course of albendazole along with dexamethazone. 


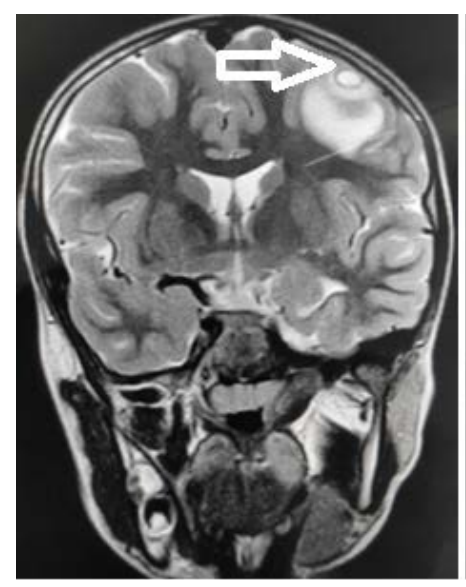

(a)

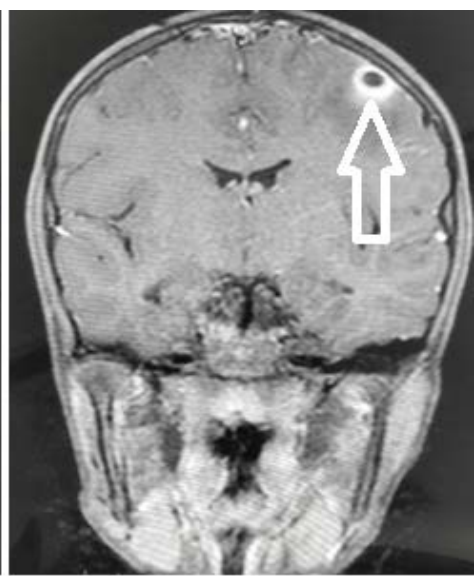

(b)

Figure 3. Case 8 of brain MRI of 7 years old female child. (a) T2W coronal section shows cystic lesion in left parietal region with perilesional edema (white arrow). (b) T1W post contrast image shows ring enhancing lesion with normal rest of the brain parenchyma (white arrow).

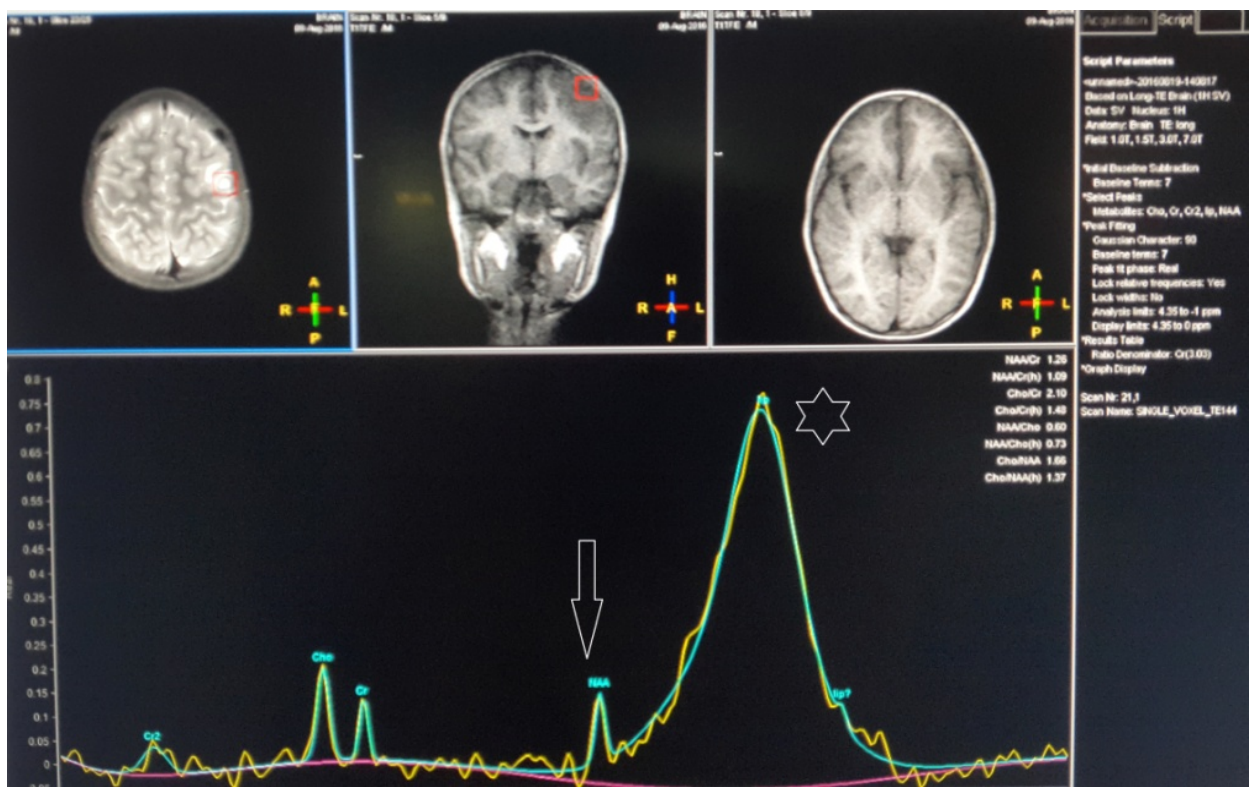

Figure 4. Case $8 \mathrm{MR}$ Spectroscopy shows increase in lipid (white star) and decrease in NAA peaks (white arrow). There is also increase in choline and decrease in creatinine peaks which confirm the underlying pathology being tuberculomas.

Cerebral tuberculomas are the result of haematogenous spread of Mycobacterium Tuberculosis [3]. Anti tubercular treatment with the four drugs (HRZE) is important for curing the disease [4]. The activity of the enhancing lesions is not related to stopping the treatment. The treatment is continued till all the lesions disappear. Tuberculomas are $1 \%$ of CNS tuberculosis and is the least presentation of the disease. There are also reports of developing fresh lesions during the therapy [5]. Poymerase chain reaction test (PCR) also helps in documenting the diagnosis [6]. Intracranial giant tuberculomas can mimic in appearance like malignant pathology [7]. 


\begin{tabular}{|c|c|}
\hline DIFFERENCE BETWEEN NEUROCYSTICERCC & AND CNS TUBERCULOMAS LESIONS \\
\hline NEUROCYSTICERCOSIS & TUBERCULOMA \\
\hline $\begin{array}{l}\text { 1. Lesions are }<20 \mathrm{~mm} \text { and may be single or multiple. } \\
\text { 2. Meningitis feature is not there. } \\
\text { 3. Present at grey-white matter junction. } \\
\text { 4. Other involvements like eyes, muscles } \\
\text { or subcutaneous tissues. } \\
\text { 5. T2W shows hyper intensity with hypointense scolex } \\
\text { in it. No midline shift and ring enhancement is there } \\
\text { depending upon the staging. } \\
\text { 6. MR spectroscopy shows multiple amino acid peaks. }\end{array}$ & $\begin{array}{l}\text { 1. Often multiple and }>20 \mathrm{~mm} \text { because of } \\
\text { conglomeration. } \\
\text { 2. Meningitis is usually associated. } \\
\text { 3. More common in posterior fossa. } \\
\text { 4. Spread is mostly secondary to infection } \\
\text { somewhere else. } \\
\text { 5. Hy pointensity seen in T2W and midline } \\
\text { shift may be present. } \\
\text { 6. MR Spectroscopy shows lipid peak. }\end{array}$ \\
\hline
\end{tabular}

Figure 5. Chart shows the main differences in the presentation of NCC and CNS tuberculomas in contrast MRI and CECT.

Jayakumar et al. (1993) has shown the enhancement pattern of intracranial tuberculomas. There is extensive perilesional edema and peripheral enhancement. The conglomerated lesions show tumor like appearance but ELISA and histological back up confirm the diagnosis [8]. Wallace et al. (1991) has studied the lesions in pediatric brain and has found to be multiple in many cases and the common location is posterior fossa. It was noticed that few fresh lesions appeared during the treatment [9]. There was complete resolution of tuberculomas in many cases leaving few with other associated findings [10]. The presence of these lesions can be life threatening or can warn for the impending danger because of their location [11]. Our Case 4 had similar type of tuberculomas because one was there in tectal plate and other in the pontine region. There can be complications of ventricular dilatation. Tectal plate lesion with edema can cause third ventricle compression leading to hydrocephalus. The timely management can avoid these complications.

\section{Conclusion}

Tuberculomas and neurocysticercosis lesions resemble in many aspects in CECT and contrast MRI but the differentiation can be made on the basis of location, number of lesions, enhancement pattern and constitutional symptoms. MR spectroscopy findings show lipid peak in the former and amino acid peak in the later. If ELISA test and histological findings combined, one can come to the conclusive diagnosis. History of seizures was mostly seen in tuberculomas. There were also associated findings of tuberculosis somewhere else in the body in case of tuberculomas.

\section{References}

[1] Bem, C., Garcia, H.H., Evans, C., Gonzalez, A.E., Verastequi, M., Tsang, V.C. and Gilman, R.H. (1999) Magnitude of the Disease Burden from Neurocysticercosis in a Developing Country. Clinical Infectious Diseases, 29, 1203-1209. http://dx.doi.org/10.1086/313470

[2] Del Brutto, O.H., Rajshekhar, V., White Jr., A.C., et al. (2001) Proposed Diagnostic Criteria for Neurocysticercosis. Neurology, 57, 177-183. http://dx.doi.org/10.1212/WNL.57.2.177

[3] Rock, R.B., Olin, M., Baker, C.A., Molitor, T.W. and Peterson, P.K. (2008) Central Nervous 
System Tuberculosis: Pathogenesis and Clinical Aspects. Clinical Microbiology Reviews, 21, 243-261. http://dx.doi.org/10.1128/CMR.00042-07

[4] Pimentel, M.L.V., Alves, S.M.V., Novis, S.A.P., Brandao, R.Z. and Neto, E.B. (2000) Intracranial Tuberculomas Developing during Treatment of Pulmonary Tuberculosis: Case Report. Arquivos de Neuro-Psiquiatria, 58, 572-577. http://dx.doi.org/10.1590/S0004-282X2000000300028

[5] Jain, S.K., Kwon, P. and Moss, W.J. (2005) Management and Outcomes of Intracranial Tuberculomas Developing during Antituberculous Therapy: Case Report and Review. Clinical Pediatrics, 44, 443-450. http://dx.doi.org/10.1177/000992280504400510

[6] Nguyen, L.N., Kox, L.F., Pham, L.D., Kuijper, S. and Kolk, A.H. (1996) The Potential Contribution of the Polymerase Chain Reaction to the Diagnosis of Tuberculous Meningitis. Archives of Neurology, 53, 771-776.

http://dx.doi.org/10.1001/archneur.1996.00550080093017

[7] Alvarez-Salgado, J.A., Ruiz-Gines, J.A., Gonzales-Sejas, A.G., Belinchon-Diego, J.M., et al. (2011) Tuberculoma Intracranial Simulando Neoplasia Maligna. Caso Clinico y Revision de la Literature. Neurocirugia, 22, 600-604.

[8] Jayakumar, P.N., Kolluri, P.V., Iyer, V., et al. (1993) Intracranial Tuberculomas. A CT Study of 52 Histologically Verified Cases. Indian Journal of Radiology and Imaging, 3, 193.

[9] Wallace, R.C., Burton, E.M., Barrett, F.F., Leggiadro, R.J., Gerald, B.E. and Lasater, O.E. (1991) Intracranial Tuberculosis in Children: CT Appearance and Clinical Outcome. Pediatric Radiology, 21, 241-246. http://dx.doi.org/10.1007/BF02018612

[10] Poonnoose, S.I. and Rajshekhar, V. (2003) Rate of Resolution of Histologically Verified Intracranial Tuberculomas. Neurosurgery, 53, 873-879. http://dx.doi.org/10.1227/01.NEU.0000083553.25421.6F

[11] Sahaiu-Srivastva, S. and Jones, B. (2008) Brainstem Tuberculomas in the Immunocompetent: Case Report and Literature Review. Clinical Neurology and Neurosurgery, 110, 302304. http://dx.doi.org/10.1016/j.clineuro.2007.11.002

Submit or recommend next manuscript to SCIRP and we will provide best service for you:

Accepting pre-submission inquiries through Email, Facebook, LinkedIn, Twitter, etc. A wide selection of journals (inclusive of 9 subjects, more than 200 journals)

Providing 24-hour high-quality service

User-friendly online submission system

Fair and swift peer-review system

Efficient typesetting and proofreading procedure

Display of the result of downloads and visits, as well as the number of cited articles Maximum dissemination of your research work

Submit your manuscript at: http://papersubmission.scirp.org/ 